\title{
„Putinowska” wizja przeszłości. Nowa koncepcja nauczania historii w świetle polityki historycznej Federacji Rosyjskiej
}

\author{
“Putin's” Vision of the Past. A New Concept for Teaching Russian History \\ in the Light of the Historical Policy of the Russian Federation
}

\begin{abstract}
The article investigates an issue of a new concept for teaching Russian history in secondary schools as a tool of creating the historical policy of the Russian Federation. It is also an attempt to prove the thesis that the new concept imposes the only version of the historical truth and provides an example of limiting the ideological pluralism. The author assume that the analysis of the document allows the reconstruction of the major historical policy directions of the Russian Federation during the third presidential term of Vladimir Putin (it is especially important in case of the controversial XX and XXI century). The subject of the research is however not only the document itself, but also the changes it brings to the teaching of history in Russian schools and its impact on the historical consciousness of the Russian youth.
\end{abstract}

Keywords: historical policy, Russian Federation, Vladimir Putin, teaching, history, concept for teaching history

Słowa kluczowe: polityka historyczna, Federacja Rosyjska, Władimir Putin, nauczanie, historia, koncepcja nauczania historii

\section{Słowem wstępu}

Wiedza szkolna, której podstawową wykładnię stanowią podręczniki, jest w Rosji powiązana z władzą i uzależniona od dominujących poglądów polityczno-społecznych. Treści zawarte w podręcznikach tylko pozornie przekazują uczniom wiedzę uniwersalną, de facto są one bowiem ilustracją ideologii legitymizującej władze państwowe ${ }^{1}$. Kształt podręczników i poradników dla nauczycieli jest doskonałym

1 M. Chomczyńska-Rubacha, D. Pankowska, Wtadza, ideologia, socjalizacja. Polityczność podręczników szkolnych, [w:] Podręczniki i poradniki. Konteksty. Dyskursy. Perspektywy, red. M. Chomczyńska-Rubacha, Kraków 2011, s. 17-18. 
źródłem wiedzy o kondycji społeczeństwa - stanowią one ilustrację obowiązujących standardów wiedzy oraz pokazują swego rodzaju sposoby kontroli umysłów odbiorców. Co więcej, podręczniki mogą stanowić przesłankę do zmian, lecz mogą także utrwalać stereotypowe i autorytarne myślenie².

Podstawowy dylemat w badaniu polityki historycznej polega na doprecyzowaniu jej rozumienia oraz przeniesieniu debaty z dyskursu popularnonaukowego do naukowego. Rozstrzygnięcie owego dylematu utrudnia m.in. funkcjonowanie w dyskursie wielu definicji polityki historycznej oraz określanie niemalże analogicznych zjawisk różnymi pojęciami (możemy się spotkać z takimi terminami jak polityczne dysponowanie pamięcią, polityka pamięci, polityka wobec pamięci, polityka historyczna w danym państwie, polityka historyczna danego państwa itp.). Na potrzeby niniejszego artykułu autorka posługuje się definicją stworzoną przez Towarzystwo Memoriał na potrzeby projektu „Monitoring polityki historycznej 2010-2012”: „Polityka historyczna to zespół działań (wydarzeń, inicjatyw), które mają na celu wytworzenie w społeczeństwie konkretnego obrazu przeszłości i jego interpretacji”’”.

Poszczególne podmioty (różnego rodzaju instytucje, partie polityczne, organizacje, władze państwowe itp.) korzystają z całego szeregu narzędzi, za pomocą których wpływają na kształt polityki historycznej. Jako przykład można podać chociażby budowanie pomników, wmurowywanie tablic pamiątkowych, nazewnictwo ulic, placów, skwerów, kalendarz świąt państwowych czy też szeroko pojętą edukację (program nauczania, podręczniki, poradniki metodyczne dla nauczycieli, publikacje naukowe, projekty badawcze itp. $)^{4}$.

\section{Polityka historyczna Federacji Rosyjskiej w trakcie obecnej kadencji Władimira Putina}

Od momentu upadku Związku Socjalistycznych Republik Radzieckich (ZSRR) i powstania niepodległego państwa rosyjskiego, Rosjanie stanęli przed trudnym

2 Taka sytuacja ma miejsce w Federacji Rosyjskiej, w której podręczniki i poradniki stanowią narzędzie w rękach władzy służące do utrwalania w odbiorcach wykreowanej przez nią wizji przeszłości, por.: M. Chomczyńska-Rubacha, Wstęp, [w:] Podręczniki i poradniki..., s. 7.

3 Ros.: „историческая политика - это совокупность действий (заявлений, инициатив) в сфере формирования и продвижения в общественном пространстве исторических сведений и их интерпретаций”. Уроки истрории XX век, Мониторинг исторической политики: o npoeкme, http://www.urokiistorii.ru/2589, odczyt z 9.08.2014.

4 Rodzaje narzędzi wykorzystywanych przez kreatorów polityki historycznej autorka zaczerpnęla z projektu realizowanego przez organizację Memoriał: Monitoring polityki historycznej (2010_ -2012), por.: Мониторинг исторической политики: о проекте, Уроки истрории ХХ век, http:// www.urokiistorii.ru/2589, odczyt z 09.08.2014. 
zadaniem odbudowania swojej tożsamości (nie została ona w pełni ukształtowana do dnia dzisiejszego). Władze doskonale zdają sobie sprawę z „rozbicia” rosyjskiej świadomości i wykorzystują to starając się narzucić społeczeństwu jedynie słuszną wizję przeszłości5. Przykładem takiego działania jest próba ujednolicenia treści zamieszczanych w podręcznikach do historii. Po objęciu urzędu prezydenckiego przez Władimira Putina w 2000 roku rozpoczął się okres świadomego kształtowania polityki historycznej przez władze, której celem było wykształcenie pożytecznej dla państwa wizji przeszłości. Doskonałym przykładem tej tendencji jest inicjatywa stworzenia jednej linii podręczników do historii Rosji oraz powołana przez prezydenta Miedwiediewa Komisja ds. przeciwdziałania próbom fałszowania historii, szkodzącym interesom Rosji ${ }^{6}$.

Polityka historyczna pierwszej kadencji Władimira Putina (2000-2008) opierała się przede wszystkim na intensywnym nawiązywaniu do ciągłości ideowej Rosji współczesnej ze Związkiem Radzieckim. Charakteryzowała się ona m.in. rehabilitacją i gloryfikacją jego mocarstwowej polityki (podkreślano m.in. zwycięstwo ZSRR nad hitlerowskimi Niemcami), nawiązywaniu do idei silnej Rosji oraz podkreślaniu takich wartości jak duma z ojczyzny, patriotyzm czy bohaterska wal$\mathrm{ka}^{7}$. Dynamika wykorzystania przeszłości przez władze uległa zmianie podczas kadencji prezydenckiej Dmitrija Miedwiediewa (2008-2012), to wówczas miała bowiem miejsce destalinizacja retoryki historycznej objawiająca się m.in. w rezygnacji z apologii Stalina. Sam Miediwediew uznał ZSRR za państwo totalitarne a działania władz imperium wobec zbrodni katyńskiej za fałszowanie historii. Co więcej, potępił także represje stalinowskie przy obchodach Dnia Pamięci Ofiar Stalinowskich 30 października 2009 roku$^{8}$.

5 W. Kutiawin, Pamięć historyczna Rosjan. Między dziejopisarstwem akademickim a historiografia. ludowa, [w:] Pamięć historyczna i polityka. Doświadczenia Polski i jej sasiadów, red. S.M. Nowinowski, J. Pomorski, R. Stobiecki, Łódź 2008, s. 36.

6 Komisja m.in. przeciwdziałania fałszowaniu historii „szkodzącym interesom Rosji” zajmowała się głównie odpieraniem krytyki pod adresem ZSRR (powołana w roku 2009, zlikwidowana w roku 2012). Celem Komisji miała być de iure naukowa interpretacja przeszłości, de facto jednak była ona narzędziem propagandowym w rękach władz. Президент России, Официальне Интернет Представительство, Указ Президента РФ от 15.05.2009 N 549 О Комиссии при Президенте Российской Федераиии по противодействию попыткам фальсификаиии истории в ущерб интересам России, http://document.kremlin.ru/doc.asp?ID=52421\&PSC=1\&PT=1\&Page=2, odczyt z 22.08.2014.

7 Szerzej na temat niektórych aspektów rosyjskiej polityki historycznej: A. Dubas, M. Menkiszak, Rosyjska kampania historyczna, Tydzień na wschodzie, 2009, nr 28(103), s. 2-3, http://www.osw.waw. pl/sites/default/files/tnw103.pdf, odczyt z 10.08.2014; M. Kaczmarski, J. Rogoża, Ewolucja rosyjskiej polityki historycznej, Tydzień na Wschodzie, 2010, nr 17(135), s. 2-3, http://www.osw.waw.pl/pl/publikacje/tydzien-na-wschodzie/2010-05-12/ewolucja-rosyjskiej-polityki-historycznej, odczyt z 10.08.2014.

8 Elementem, który nie uległ zmianie było podkreślanie roli ZSRR w II wojnie światowej jako kraju, który uratował państwa europejskie przed nazistowskimi Niemcami. 
Trzecia kadencja prezydencka Władimira Putina (2012 - dzisiaj) charakteryzuje się powrotem do twardej retoryki historycznej widocznej w trakcie jego dwóch pierwszych kadencji. Przykładem powrotu do symboliki imperium radzieckiego jest odrestaurowanie tytułu Bohatera Pracy Socjalistycznej (przyznawany od 1938 roku za szczególne zasługi dla ZSRR) - Putin dekretem prezydenckim z 29 marca 2013 roku' ustanowił tytuł Bohatera Pracy Federacji Rosyjskiej. Co więcej, władze Wołgogradu w styczniu 2013 roku przyjęły ustawę przywracającą incydentalnie nazwę Stalingrad podczas uroczystości związanych z Wielką Wojną Ojczyźnianą (m.in. 2 lutego - rocznica zwycięstwa w bitwie stalingradzkiej, 9 maja - Dzień Zwycięstwa, 22 czerwca - rocznica najazdu hitlerowskich Niemiec na ZSRR) ${ }^{10}$.

Zmiany nie ominęły również środków masowego przekazu. Dekretem prezydenckim z 9 grudnia 2013 roku Putin dokonał likwidacji agencji informacyjnej Ria Novosti oraz rozgłośni radiowej Głos Rosji. Na ich miejsce powstało Federalne Państwowe Zjednoczone Przedsiębiorstwo Międzynarodowa Agencja Informacyjna Rossija Siegodnia ${ }^{11}$ na czele której stanął prokremlowski dziennikarz Dmitrij Kisieliow. Celem nowej agencji informacyjnej ma być „naświetlanie za granicą polityki Federacji Rosyjskiej i rosyjskiego życia publicznego"12 oraz kreowanie pozytywnego wizerunku Rosji na świecie. Ma ona również za zadanie, zgodnie z obowiązującym ją prawem, realizować misję ,informacyjno-propagandowego wsparcia wewnętrznej i zewnętrznej polityki Federacji Rosyjskiej”. Krok ten idealnie wpisuje się w politykę kontrolowania niewygodnych dla Kremla mediów (konsolidacja kontroli nad mediami) $^{13}$.

\section{Idea nowej koncepcji nauczania historii w rosyjskich szkołach}

Doskonałym przykładem zmian w polityce historycznej trzeciej kadencji Putina jest idea stworzenia nowej koncepcji nauczania historii w szkołach (tekst liczy ok.

9 Указ Президента Российской Федерации от 29 марта 2013 года № 294 Обустановлении звания Героя Труда Российской Федераиии, http://ivo.garant.ru/SESSION/PILOT/main.htm, odczyt z 10.08.2014.

10 Волгоград в памятнье дни станет Сталинградом, http://enta.ru/news/2013/01/31/stalingrad/, odczyt z 10.08.2014.

11 Ros. Федеральное государственное унитарное преАприятие межАународное информационное агентство „Россия сегодня”.

12 Указ омерах по повышению эффективности деятельности государственных СМИот 9 декабря 2013 года, Президент России официальный сайт, http://news.kremlin.ru/news/19805, odczyt z 11.08.2014.

13 Jako oficjalny powód likwidacji Ria novosti podano konieczność ograniczenia wydatków budżetowych na środki masowego przekazu. 
80 stron, jego najważniejszym założeniem jest stworzenie jednej linii podręczników do szkoły średniej) $)^{14}$. Zdaniem jej twórców, ma ona godzić różne spojrzenia na dzieje Federacji Rosyjskiej i Związku Socjalistycznych Republik Radzieckich, uczyć samodzielnego myślenia, miłości do Ojczyzny oraz stanowić obiektywną wykładnię przeszłości ${ }^{15}$. De facto jednak, koncepcja doskonale wpisuje się w retorykę władz charakteryzującą się szerzeniem uczucia patriotyzmu, obywatelskości i dumy z Ojczyzny oraz narzucaniem społeczeństwu jednej wykładni historii (funkcja integracyjna polityki historycznej).

Idea stworzenia nowych standardów nauczania, której autorem jest nominalnie sam prezydent Putin, narodziła się w lutym 2013 roku $^{16}$, a prace nad jej stworzeniem zakończyły się 30 października tego samego roku. Oficjalnym powodem powstania dokumentu był wyraźny brak zgody głowy państwa na funkcjonowanie w obiegu podręczników przedstawiających różne punkty widzenia na kluczowe dla Rosji momenty z przeszłości. Stworzeniem koncepcji zajęła się grupa robocza Rosyjskiego Towarzystwa Historycznego pod kierownictwem przewodniczącego Dumy Państwowej FR Siergieja Naryszkina ${ }^{17}$ (przewodniczący grupy roboczej), Ministra Edukacji i Nauki FR Dmitrija Liwanowa oraz Ministra Kultury FR Władimira Medińskiego. Kierownikiem naukowym projektu został natomiast dyrektor Instytutu Historii Powszechnej Rosyjskiej Akademii Nauk Aleksandr Czubarjan $^{18}$. W pracy nad koncepcją udział wzięli historycy, nauczyciele, organizacje społeczne oraz przedstawiciele poszczególnych podmiotów FR (twórcom zależało na szerokiej konsultacji społecznej) - w sumie w pracy nad stworzeniem dokumentu wzięło udział ponad 1000 osób $^{19}$.

14 Tekst koncepсji: Конщепция нового учебно-методического комплекса по отечественной ucmopuu, http://school.historians.ru/wp-content/uploads/2013/10/2013.10.21-\%D0\%9A\%D0\%B E\%D0\%BD\%D1\%86\%D0\%B5\%D0\%BF\%D1\%86\%D0\%B8\%D1\%8F_\%D0\%B4\%D0\%BB $\%$ D $1 \% 8$ F- $\%$ D $1 \% 80 \%$ D0\%B0\%D0\%B7\%D0\%BC\%D0\%B5\%D1\%89\%D0\%B5\%D0\%BD\% D0\%B8\%D1\%8F.pdf, odczyt z 11.08.2014.

15 Портал «Президент России»: Встреча савторами конщепчии нового учебника истории, http://school.historians.rul:p=1275, odczyt z 10.08. 2014.

16 Tworzenie koncepcji nauczania historii zostało zakończone, prace nad nowym podręcznikiem natomiast jeszcze trwają.

17 Siergiej Naryszkin był przewodniczącym 28 osobowej Komisji ds. przeciwdziałania próbom fałszowania historii, szkodzącym interesom Rosji, która funkcjonowała w FR w latach 2009-2012.

18 Состав рабочей группы по подготовке концепции нового учебно-методического комплекса по отечественной истории, Министерство Образования и Науки Российской Федерации, http://xn--80abucjiibhv9a.xn--plai/\%D0\%B4\%D0\%BE\%D0\%BA\%D1\%83\%D0\%BC\%D0\%B 5\%D0\%BD\%D1\%82\%D1\%8B/3967, odczyt z 12.08.2014.

19 Концепия нового учебно-методического комплекса по отечественной истории, Институт Российской Историй PAH, http://www.iriran.ru/?q=node/1039, odczyt z 12.08.2014. 
Nowa koncepcja to jednak nie tylko wprowadzenie jednego podręcznika mającego na celu ujednolicenie treści nauczania, to także podwyższanie kwalifikacji nauczycieli (metodyczne i merytoryczne szkolenia, specjalne broszury, poradniki itp.). Podręcznik ma zostać wprowadzony do obiegu w przeciągu dwóch lat (licząc od roku 2013), koncepcja natomiast ma zacząć funkcjonować już od roku akademickiego 2014/2015 (dopuszczenie do obiegu podręczników do historii zgodnych z wykładnią koncepcji, przeprowadzenie szkoleń dla nauczycieli itp. ${ }^{20}$. Inicjatywa budzi wiele kontrowersji przede wszystkim ze względu na próbę monopolizacji dyskursu historycznego, zaś najwięcej emocji pojawiło się w związku z opracowaniem jednej interpretacji historii XX i XXI wieku. Co więcej, koncepcja ilustruje sposób myślenia rosyjskich władz oraz iluzoryczne wprowadzenie pluralizmu polityczno-kulturowego po upadku imperium radzieckiego.

\section{Analiza nowej koncepcji nauczania historii}

Nowa koncepcja nauczania historii w rosyjskich szkołach średnich obejmuje wyłącznie historię ojczystą, niemniej jednak pojawiły się pomysły wprowadzenia podobnej inicjatywy dla historii powszechnej (zaznacza się przy tym, że historia ojczysta jest podstawą nauczania historii w szkołach). Co więcej, podkreśla się również potrzebę stworzenia analogicznych koncepcji dla innych przedmiotów humanistycznych (m.in. literatury i języka rosyjskiego) oraz zmianę w organizacji i przebiegu egzaminów z historii po dziewiątej (Gosudarstwiennaja Itogowaja Attestacija) i jedenastej klasie (egzamin maturalny: Jedinyj Gosudarstwiennyj Ekzamien) szkoły średniej ${ }^{21}$.

Celem koncepcji jest powstanie jednej linii podręczników do historii ojczystej dla szkół szczebla średniego, ma ona jednak wpłynąć również na program nauczania szkoły podstawowej (w klasach 1-4 nie ma przedmiotu o nazwie historia, jej elementy zawarte są w przedmiocie: otaczający świat ${ }^{22}$ ). Założeniem jest także stworzenie nowych map historycznych, jednolitych poradników dla nauczycieli i ujednoliconej przestrzeni edukacyjnej w Internecie. Częścią dokumentu jest tzw. kulturowo-historyczny standard ${ }^{23}$ stanowiący naukową podstawę nauczania historii w szkołach zarówno na poziomie podstawowym, jak i rozszerzonym. Składa się on z oceny najważniejszych wydarzeń historycznych oraz listy rekomendowa-

\footnotetext{
20 Портал «Президент России»: Встреча с авторами...

21 Кониепия нового..., s. 3.

22 Ros. окружающий мир.

23 Ros. историко-культурный стандарт.
} 
nych pojęć, wydarzeń i postaci z przeszłości. Wskazuje ponadto, w jaki sposób powinno się nauczać historii ojczystej we współczesnej szkole ${ }^{24}$.

Każdy rozdział (w sumie Koncepcja liczy 19 rozdziałów i tzw. listę trudnych zagadnień) składa się ze wstępu charakteryzującego dany okres historyczny, krótkiego chronologicznego opisu najważniejszych zagadnień (np. najazd mongolski) oraz, w niektórych przypadkach, opisu kultury (architektura, literatura, malarstwo). Kolejnym elementem jest lista pojęć i osób (np. działacze państwowi i wojenni, społeczni i religijni, kultury, nauki, oświaty), źródła historyczne wzbogacające literaturę przedmiotu (np.: Powieść laty minionych, Konstytucja FR, ustawy, dekrety itp.) oraz najważniejsze daty i wydarzenia. Założeniem koncepcji jest przedstawienie dziejów państwa rosyjskiego jako składowej historii poszczególnych narodów wchodzących w jego skład oraz podkreślenie, że historia Rosji stanowi nieodłączną część historii powszechnej.

Do celów i założeń koncepcji należy m.in. wprowadzenie wyższego poziomu nauczania historii ojczystej w szkołach średnich, kształtowanie tożsamości narodowej młodego pokolenia oraz zapewnienie konsolidacji i jedności rosyjskiego społeczeństwa. Ponadto, jej zadaniem jest również stworzenie odpowiednich warunków dla zdobycia przez uczniów kompleksowej wiedzy historycznej, pokazanie etapów rozwoju wielonarodowego państwa rosyjskiego, przedstawienie historii Rosji jako efektu działania wielu pokoleń Rosjan. Koncepcja, a co za tym idzie, nowa linia podręczników, ma pomóc uczniom w zrozumieniu miejsca i roli współczesnej Rosji w świecie (w tym wzmocnić w nich poczucie dumy z Ojczyzny poprzez podkreślanie heroizmu żołnierzy w Wojnie Ojczyźnianej 1812 roku i Wielkiej Wojnie Ojczyźnianej lat 1941-1945), nauczyć samodzielnego myślenia i wyciągania wniosków oraz określić wymagania dotyczące treści kształcenia i edukacji, organizacji procesu kształcenia i zajęć pozaszkolnych na wszystkich poziomach. Co więcej, inicjatywie przyświeca cel nauczania w duchu patriotyzmu i szacunku dla wielonarodowego państwa rosyjskiego zgodnie z ideą wzajemnego zrozumienia, tolerancji i pokoju między ludźmi i narodami oraz demokratycznych wartości współczesnego państwa ${ }^{25}$.

Po przeanalizowaniu koncepcji dowiadujemy się, iż ma ona formę umowy społecznej podkreślającej najbardziej dyskusyjne elementy historii ojczystej oraz powszechnej przy zachowaniu pluralizmu w jej ocenach. Co więcej, dokument opiera się na podstawowych wartościach społeczeństwa obywatelskiego takich jak solidarność społeczna, wolność, odpowiedzialność i tolerancja ${ }^{26}$.

\footnotetext{
24 Концепия нового..., s. 2.

25 Ibidem, s. 2-3, 5-6.

26 Ibidem, s. 4-5.
} 
Zgodnie z koncepcją, historia powinna przedstawiać dzieje państwa rosyjskiego z zaznaczeniem roli, jaką odgrywały w niej poszczególne narody, mniejszości etniczne, regiony i miasta (historia regionalna i lokalna), co ma umożliwić ukształtowanie się tożsamości lokalnej oraz utożsamienie się przez obywateli ze wspólnym kulturowo-historycznym dziedzictwem. Co więcej, historia ma nauczyć uczniów dialogu międzykulturowego oraz szacunku dla osiągnięć kultury zarówno swojej, jak i innych narodów. Nauczanie powinno ponadto zawierać elementy charakteryzujące politykę zagraniczną i wewnętrzną państwa rosyjskiego, jego kulturę, gospodarkę i relacje na linii państwo-obywatel ${ }^{27}$. Uczniowie muszą mieć świadomość, że Rosja doświadczyła zarówno okresów triumfalnych jak i tragicznych (jako przykład podaje się np.: Wielką Smutę, rewolucję październikową oraz represje polityczne), a kurs historii ma za zadanie ukształtowanie w nich odpowiedzialności obywatelskiej (problem zaangażowania obywatelskiego, praw i obowiązków obywateli, budowa społeczeństwa obywatelskiego itp.). Podkreśla się także potrzebę zwiększenia ilość lekcji poświęconych historii kultury, uczniowie powinni znać bowiem wielkie dzieła literatury, muzyki, malarstwa, teatru, kina, odkrycia rosyjskich naukowców itp. Analogicznie do historii ojczystej i powszechnej, zaznacza się duże powiązanie łączące kulturę rosyjską i światową ${ }^{28}$.

W koncepcji znajdziemy również informacje o tym, w jaki sposób powinien wyglądać nowy kompleksowy zestaw do nauczania historii. Składa się on przede wszystkim z podręcznika, który ma służyć nie tylko przekazywaniu informacji, lecz także uczyć samodzielnego myślenia i analizowania tekstów historycznych, wyciągania wniosków oraz szukania informacji w innych źródłach historycznych. Kolejne elementy to atlas historyczny, zbiór zadań (ćwiczenia) i zbiór dokumentów. Uczniowie powinni umiejętnie korzystać także z zasobów internetowych ${ }^{29}$. Koncepcja wskazuje również $\mathrm{w}$ jakie materiały powinien być wyposażony nauczyciel w tym m.in.: dokumentacja prawna i metodyczna (kulturowo-historyczny standard oraz przykładowy program nauczania historii), podręczniki przedmiotowe i metodyczne. W szkołach nie może natomiast zabraknąć map historycznych, tablic chronologicznych, encyklopedii, ilustracji, e-booków, albumów multimedialnych itp. ${ }^{30}$ Nowoczesny podręcznik do nauczania historii powinien być uniwersalnym nośnikiem informacji o przeszłości i zawierać kompletny obraz historyczny wraz z prezentacją materiałów historycznych (tekst autorski, źródła, materiały graficzne itp.). Nie może oceniać faktów lecz je przedstawiać w taki sposób,

\footnotetext{
27 Ibidem, s. 6-8.

28 Ibidem.

29 Ibidem, s. 10.

30 Ibidem, s. 10-11.
} 
aby uczniowie na ich podstawie mogli samodzielnie wyciągać wnioski. Podręcznik powinien być „nawigatorem” w naukowo-edukacyjnej przestrzeni historycznej ${ }^{31}$.

Ostateczna wersja dokumentu obejmuje okres od czasów Rusi Kijowskiej do roku 2012. Dokument cechuje względny obiektywizm w przedstawianiu wydarzeń i postaci z przeszłości (np. przy omawianiu okresu panowania Iwana IV Groźnego jest mowa zarówno o jego reformach, jak i o despotycznych rządach). Celem niniejszego artykułu nie jest dokładna analiza wszystkich zagadnień przedstawionych w koncepcji (zabrakłoby na to miejsca), wobec czego skupię się na wydarzeniu mającym ogromny wpływ na współczesna politykę historyczną FR, a mianowicie na micie zwycięstwa w Wielkiej Wojnie Ojczyźnianej (WWO). W rozdziale zatytułowanym "Wielka Wojna Ojczyźniana. 1941-1945” podkreśla się, że walka ZSRR przeciwko hitlerowskim Niemcom i ich satelitom była niezwykle ważną częścią II wojny światowej. Nie brakuje przy tym danych liczbowych: w II wojnie światowej udział wzięły 72 państwa, w których żyło wówczas $80 \%$ ludności świata. Jednak to wydarzenia na froncie radziecko-niemieckim miały najbardziej gwałtowny i krwawy charakter: 70-80 \% strat niemieckich w czasie II wojny światowej miało miejsce podczas WWO. Nacisk został położony na ogromną rolę, jaką Związek Radziecki odegrał w zwycięstwie nad hitlerowskimi Niemcami, przytoczone zostały również dane ilustrujące poniesione przez niego starty: z ogólnej liczby ofiar II wojny światowej (55 mln ludzi), ZSRR poniósł straty największe (27 mln żołnierzy i cywilów). Dla porównania podano, że Stany Zjednoczone i Wielka Brytania poniosły łącznie straty rzędu $1 \mathrm{mln}$ ludzi. Podkreślono również, że dla Związku Radzieckiego wojna lat 1941-1945 była wojną ojczyźnianą, angażującą wszystkie narody państwa rosyjskiego, świętą wojną o przetrwanie i zachowanie swojej państwowości, a zwycięstwo stało się jedną z podstaw patriotycznej postawy oraz jedności wszystkich narodów wchodzących w skład ZSRR (nie udało się nazistom skłócić narodów imperium radzieckiego). Wskazano również, że za wyjątkową odwagę i bohaterstwo w czasie WWO ponad 11.6 tys. osób nagrodzono tytułem Bohatera Związku Radzieckiego, a za intensywną pracę w czasie wojny 204 osoby otrzymały tytuł Bohatera Pracy Socjalistycznej (tytuł przywrócony przez Władimira Putina w 2013 roku). Wyraźnie podkreślono również, iż po zwycięstwie w WWO Związek radziecki stał się światowym supermocarstwem (mocarstwowość państwa rosyjskiego jest jedną z podstawowych wartości wykorzystywanych w polityce historycznej prowadzonej przez FR) ${ }^{32}$.

\footnotetext{
31 Ibidem.

32 Ibidem, s. 57-62.
} 
Ciekawym przykładem względnie obiektywnego przedstawienia postaci z przeszłości jest osoba Józefa Stalina. W koncepcji zwrócono uwagę zarówno na wzmocnienie ideologicznej cenzury, masowe represje polityczne, Gułag i prace przymusowe więźniów, jak i na rolę organów bezpieczeństwa w zabezpieczeniu rządów wodza, kontrolę ideologiczną społeczeństwa, wprowadzenie dyktatury wodza i kult jednostki ${ }^{33}$. Dokument nie wspomina jednak nic o pakcie Ribbentrop-Mołotow, czy zbrodni katyńskiej. Wybiórczość w podejściu do najnowszej historii Rosji można pokazać także na przykładzie spisu ważnych postaci XXI wieku. Nie ma w nim m.in.: oligarchów Michaiła Chodorkowskiego i Borysa Bieriezowskiego, jest natomiast nazwisko lidera Liberalno-Demokratycznej Partii Rosji Władimira Żyrinowskiego oraz byłego prezydenta Czeczenii Achmada Kadyrowa. W sposób tendencyjny przywołuje się również dane liczbowe: w dokumencie podano liczbę ofiar II Wojny Światowej, nie ma jednak informacji o ofiarach represji stalinowskich.

\section{Standard nauczania na różnych stopniach edukacji i lista trudnych zagadnień}

Koncepcja przedstawia w jaki sposób powinno wyglądać nauczanie historii na różnych etapach szkolonej edukacji. I tak, w szkole podstawowej (klasy 1-4) uczniowie poznają dzieje państwa rosyjskiego z uwzględnieniem historii swojej rodziny, miasta, regionu i różnych narodów zamieszkujących FR. To wówczas kształtują się w nich podstawowe przekonania historyczne i kulturowe. W szkole średniej natomiast (klasy 5-9), uczniowie przechodzą kurs historii Rosji i historii powszechnej, rozwijają wiedzę o poszczególnych etapach rozwoju państwa rosyjskiego i jego miejsca w historii świata. Podobnie jak w szkole podstawowej, poznają historię ojczystą z uwzględnieniem dziejów swojej rodziny, miasta, regionu i poszczególnych narodów. W klasach 10-11, które kończą się zdaniem egzaminu maturalnego, uczniowie przechodzą poszerzony kurs historii ojczystej i powszechnej mający na celu poszerzenie ich światopoglądu. Nauczanie rozbudowane jest o źródła historyczne, prowadzi się analizę porównawczą dziejów Rosji i świata. Uczniowie nabywają umiejętności oceniania przeszłości (rozróżnienie prawdy od fałszu) ${ }^{34}$. W dokumencie podkreślono, że na każdym etapie kształcenia szkoły mają możliwość tworzenia indywidualnego programu nauczania w oparciu o założenia koncepcji.

\footnotetext{
33 Ibidem, s. 55, 66.

34 Конщепия нового..., s. 12-13.
} 
Ostatnim elementem koncepcji jest tzw. lista trudnych zagadnień stworzona w celu ujednolicenia interpretacji kontrowersyjnych wydarzeń rosyjskiej historii. Ma ona stanowić podstawę do opracowania dodatkowych materiałów dla nauczycieli zawierających możliwie najbardziej wspólny pogląd na problemowe zagadnienia (seria poszerzonych modułów tematycznych) ${ }^{35}$. Rozwiązanie to wskazuje z jednej strony na pluralizm ideologiczny i możliwość dyskusji, z drugiej jednak stanowi impuls do narzucenia uczniom i nauczycielom jednej wizji interpretacji problemowych zagadnień. Do najciekawszych pozycji z listy należą bez wątpienia te, które związane są z kontrowersyjnym wiekiem XX w tym m.in.:

Charakter polityki bolszewików i jej ocena.

Przyczyny, skutki i ocena ustanowienia monopartyjnej dyktatury i jedynowładztwa Stalina; przyczyny represji.

1. Ocena polityki zagranicznej ZSRR w, przed oraz w trakcie II Wojny Światowej;.

2. Koszty zwycięstwa ZSRR w Wielkiej Wojnie Ojczyźnianej.

3. Ocena ZSRR w okresie „zimnej wojny”.

4. Przyczyny, skutki i ocena reform Chruszczowa.

5. Ocena okresu władzy Breżniewa i roli ruchu dysydenckiego.

6. Przyczyny, skutki i ocena „pieriestrojki” oraz upadku ZSRR.

7. Ocena przyczyn, charakteru i skutków reform gospodarczych początku 1990 lat (terapia szokowa, metody prywatyzacji); przyczyny i skutki zwycięstwa Jelcyna w bataliach politycznych lat dziewięćdziesiątych ${ }^{36}$.

35 Ibidem, s. 8-9, 80 .

36 Ros.:

1. характер национальной политики большевиков и ее оценка;

2. причины, последствия и оценка установления однопартийной диктатуры и еАиновластия И.В. Сталина; причины репрессий;

3. оценка внешней политики СССР накануне и в начаме Второй мировой войны;

4. цена победы СССР в Великой Отечественной войне;

5. оценка СССР в условиях «холодной войны»;

6. причины, последствия и оценка реформ Н.С. Хрущева;

7. оценка периода правления А.И. Брежнева и роли диссидентского Авижения;

8. причины, последствия и оценка «перестройки» и распада СССР;

9. оценка причин, характера и последствий экономических реформ начала 1990-х гг. («шоковая терапия», методы приватизации); причины и последствия побеА Б.Н. Ельцина в политических схватках 1990-х гг.;

Концепия нового учебно-методического комплекса по отечественной истории, s. 80, http://school.historians.ru/wp-content/uploads/2013/10/2013.10.21-\%D0\%9A\%D0\%BE \%D0\%BD\%D1\% 86\%D0\%B5\%D0\%BF\%D1\%86\%D0\%B8\%D1\%8F_\%D0\%B4\%D0\% BB $\%$ D $1 \% 8$ F-\%D1\% 80\%D0\%B0\%D0\%B7\%D0\%BC\%D0\%B5\%D1\%89\%D0\%B5\%D0\%BD\%D0\%B8\%D1\%8F.pdf, odczyt z 11.08.2014. 
W lutym 2014 roku, na spotkaniu Władimira Putina z autorami koncepcji, prezydent podkreślił, że nowa linia podręczników do historii nie oznacza narzucania jedynie słusznej ideologii, ma mianowicie na celu wprowadzenie jednej logiki w przedstawianiu historii, uczenie rozumienia procesów przyczynowo-skutkowych oraz umiejętności znajdywania powiązań pomiędzy poszczególnymi etapami rozwoju FR. Putin zaznaczył również, że nawet najbardziej kontrowersyjne wydarzenia historii Rosji są jej integralną częścią (nie wspomniał jednak o jakie wydarzenia chodzi), wszystkie różnice w ocenie przeszłości należy szanować (niezbędna jest obiektywna ocena wydarzeń z przeszłości, a historia ojczysta stanowi podstawę tożsamości współczesnych Rosjan ${ }^{37}$.

Przewodniczący Towarzystwa Historycznego Siergiej Naryszkin zwrócił uwagę, że obecnie w Rosji jest bardzo duże zapotrzebowanie społeczne dla badań historycznych w związku z czym ich wsparcie przez władze oraz popularyzacja wiedzy historycznej powinna być ważniejsza niż kiedykolwiek wcześniej ${ }^{38}$. Minister Edukacji i Nauki Dmitrij Liwanow podkreślił z kolei, że na napisanie nowych podręczników potrzebne jest ok 1,5 - 2 lata, jednak już teraz ma miejsce weryfikacja podręczników dopuszczanych do obiegu na podstawie zestawień sporządzanych każdego roku przez Ministerstwo Edukacji i Nauki FR (federalne listy podręczników). W następnym roku akademickim (2014/2015) do obiegu zostaną dopuszczone tylko te podręczniki, które będą zgodne z nową inicjatywą. Liwanow zaznaczył także, że organizowane będą szkolenia dla nauczycieli szkół średnich (ok 60 tys. osób) mające przygotować ich do wdrożenia założeń nowej koncepcji. Zdaniem dyrektora Instytutu Historii Powszechnej Rosyjskiej Akademii Nauk Aleksandra Czubarjana, celem koncepcji jest zaszczepienie w młodym pokoleniu dumy z Ojczyzny, szacunku oraz odpowiedzialności zarówno za historię państwa rosyjskiego, jak i jego teraźniejszość i przyszłość39.

Zgodnie z wynikami badania opinii publicznej przeprowadzonym w sierpniu 2013 roku przez Ogólnorosyjskie Centrum Badań Opinii Publicznej (WCIOM) ${ }^{40}$, aż 52 proc. ankietowanych dowiedziało się o planach wprowadzenia jednego podręcznika do historii dopiero od socjologów przeprowadzających ankietę, 35 proc. słyszało o inicjatywie ogólne informacje, a jedynie 11 proc. dokładnie

37 Встреча Президента России Владимра Путина с авторами конщепиии, Российское Историческое Общество, http://rushistory.org/?page_id=2424, odczyt z 22.08.2014.

38 Ibidem.

39 Ibidem.

40 Sondaż przeprowadzony w dniach 21-22 lipca 2013, wywiad z 1600 osób z 42 obwodów, krajów i republik FR. Błąd statystyczny nie przekracza 3,4\%. 
wiedziało na czym ona polega. Co ciekawe, 58 proc. badanych popiera powstanie jednego podręcznika, a jedynie 16 proc. jest temu przeciwna (z czego 89 proc. nie potrafiło powiedzieć dlaczego, jedynie 4 proc. stwierdziło, że powinno się uczyć różnych punktów widzenia, 3 proc., że jeden podręcznik do historii oznacza fałszowanie faktów, a 2 proc., że autorzy narzucają w ten sposób swoją interpretację dziejów $)^{41}$. Z czego wynika tak duże poparcie wprowadzenia jednego podręcznika do historii przy stosunkowo niskim poziomie wiedzy o nim? Wydaje się być to $\mathrm{z}$ jednej strony rezultatem zaspokojenia potrzeby wpisania dziejów Rosji w stałe ramy interpretacyjne, z drugiej zaś lojalności społeczeństwa rosyjskiego wobec władz państwowych.

\section{Podsumowanie}

Najważniejszym wnioskiem nasuwającym się po przeanalizowaniu nowej koncepcji nauczania historii ojczystej w rosyjskich szkołach jest obecność tendencji do przemilczania aspektów stawiających ZSRR i Rosję XX wieku w negatywnym świetle (m.in. pakt Ribbentrop-Mołotow, zbrodnia katyńska, atak terrorystyczny na szkołę w Biesłanie itp.). Wpływa to na ograniczenie pluralizmu ideologicznego w rosyjskich szkołach oraz na ukształtowanie obywatela dumnego z historii swojego kraju, który nie ma świadomości ważnych dla dziejów swojego państwa zdarzeń. Co więcej, rosyjska polityka historyczna podporządkowuje ocenę przeszłości bieżącej koniunkturze politycznej oraz ma na celu skonsolidowanie społeczeństwa wokół władzy (funkcja integracyjna polityki historycznej). W dokumencie wielokrotnie zaznaczono rolę ZSRR w Wielkiej Wojnie Ojczyźnianej oraz heroizm i bohaterstwo walczących w niej żołnierzy (mit WWO). Nie zapomniano również o podkreśleniu faktu, że dzieje państwa rosyjskiego, to historia wszystkich zamieszkujących go narodów.

Treści podręczników są w Rosji powiązane z władzą i uzależnione od panującej ideologii oraz dominujących poglądów polityczno-społecznych. Wpływają na kształt tożsamości narodowej współczesnych Rosjan oraz na postrzeganie przez nich przeszłości. Najbardziej prawdopodobne jest, że nowa linia podręczników nie będzie impulsem do zmian, lecz utrwali autorytarne myślenie władz i wpisze się doskonale w putinowską politykę historyczną, dla której imperialne myślenie,

41 Россияне „за" единьй учебник по истории, Российская Газета, http://www.rg.ru/2013/08/16/ uchebnik-site.html, odczyt z 22.08.2014. 
patriotyzm i duma z ojczyzny są podstawowymi wartościami. Nauczanie historii w Rosji nadal będzie sprowadzało się do nauki poprawności historycznej, a nie nauki krytycznego myślenia historycznego ${ }^{42}$, a nowa linia podręczników będzie przekazywać wiedzę w postaci gotowych sądów historycznych tzn. ze wszystkimi uogólnieniami, wyjaśnieniami i sądami wartościującymi.

${ }^{42}$ J. Pomorski, Ucieczka od historii jako element poprawności politycznej - tezy, [w:] Pamięć i polityka historyczna..., s. 115. 